\title{
PENGERTIAN NEGARA
}

\author{
Wisesa Atha Raihan \\ Email: atharaihanw@gmail.com \\ No BP: 2010003600285 \\ UNIVERSITAS EKASAKTI PADANG
}

\section{A. PENDAHULUAN}

Keberadaan UUD 1945 yang selama ini disakralkan, dan tidak boleh diubah kini telah mengalami beberapa perubahan. Tuntutan perubahan terhadap UUD 1945 itu pada hakikatnya merupakan tuntutan bagi adanya penataan ulang terhadap kehidupan berbangsa dan bernegara. Atau dengan kata lain sebagai upaya memulai "kontrak sosial" baru antara warga negara dengan negara menuju apa yang dicita-citakan bersama yang dituangkan dalam sebuah peraturan dasar (konstitusi). Perubahan konstitusi ini menginginkan pula adanya perubahan sistem dan kondisi negara yang otoritarian menuju kearah sistem yang demokratis dengan relasi lembaga negara yang seimbang. Dengan demikian perubahan konstititusi menjadi suatu agenda yang tidak bisa diabaikan. Hal ini menjadi suatu keharusan dan amat menentukan bagi jalannya demokratisasi suatu bangsa. Realitas yang berkembang kemudian memang telah menunjukkan adanya komitmen bersama dalam setiap elemen masyarakat untuk mengamandemen UUD 1945. Bagaimana cara mewujudkan komitmen itu dan siapa yang berwenang melakukannya serta dalam situasi seperti apa perubahan itu terjadi, menjadikan suatu bagian yang menarik dan terpenting dari proses perubahan konstitusi itu. Karena dari sini akan dapat terlihat apakah hasil dicapai telah merepresentasikan kehendak warga masyarakat, dan apakah telah menentukan bagi pembentukan wajah Indonesia kedepan. Wajah Indonesia yang demokratis dan pluralistis, sesuai dengan nilai keadilan sosial, kesejahteraan rakyat dan 
kemanusiaan. Dengan melihat kembali dari hasil-hasil perubahan itu, kita akan dapat dinilai apakah rumusan-rumusan perubahan yang dihasilkan memang dapat dikatakan lebih baik dan sempurna. Dalam artian, sampai sejauh mana rumusan perubahan itu telah mencerminkan kehendak bersama. Perubahan yang menjadi kerangka dasar dan sangat berarti bagi perubahan-perubahan selanjutnya. Sebab dapat dikatakan konstitusi menjadi monumen sukses atas keberhasilan sebuah perubahan. 


\section{B. PEMBAHASAN}

\section{Pengertian Negara}

Negara merupakaan salah satu bentuk organisasi yang ada dalam kehidupan masyarakat. Pada prinsipnya setiaap warga mayaraka menjadi anggota dari suatu negara dan harus tunduk pada kekuasaan negara. Melalui kehidupan bernegara dengan pemerintah yang ada di dalamnya, masarakat ingin mewujutkan tujuan tujuan tertentu sepertti teerwujudnya kertentaraman, ketertiban, dan kesejahteraan masyrakat.

Agar pemerintah suatu negara memiliki kekuasaan untuk mengatur kehidupan masayakat tidak bertindak seenaknya, maka ada system aturan tersebut menggambarakan suatu hierakhi atau pertindakan dalam aturan yang paliing tinggi tingkatanya sampai pada aturan yng paling rendah.

Negara dan konstitusi adalah dwitunggal. Jika diibaratkan bangunan, negara sebagai pilar-pilar atau tembok tidak bisa berdiri kokoh tanpa pondasi yang kuat, yaitu konstitusi Indonesia. Hampir setiap negara mempunyai konstitusi, terlepas dari apakah konstitusi tersebut telah dilaksanakan dengan optimal atau belum. Yang jelas, konstitusi adalah perangkat negara yang perannya tak bisa dipandang sebelah mata.

\section{Pengertian Bangsa dan Negara}

Suatu_kelompok manusia yang dianggap memiliki identitas bersama, dan mempunyai kesamaan bahasa, agama, budaya, dan sejarah. Dalam pengertian lainnya, bangsa adalah sekelompok manusia yang dipersatukan karena memiliki persamaan sejarah dan cita-cita yang mana mereka terikat di dalam satu tanah air. Sedangkan, pengertian bangsa dalam arti sosiologis/antropologis adalah perkumpulan orang yang saling membutuhkan dan berinteraksi untuk mencapai tujuan bersama dalam suatu wilayah Sedangkan, dalam arti politis Pengertian

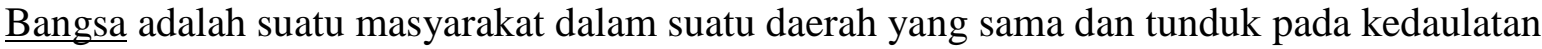


negara sebagai satu kekuasaan tertinggi ke luar dan ke dalam.

Dalam Insiklopedia Indonesia, dasar Negara berarti pedoman dalam mengatur kehidupan penyelenggaraan ketatanegaraan Negara yang mencakup berbagai kehidupan. Dasar Negara yang di gunakan di Indonesia adalah Pancasila, nilai-nilai luhur yang terkandung. Pancasila telah ada dalam kalbu bangsa jauh sebelum Indonesia merdeka.

Secara historis pengertian Negara senantiasa berkembang sesuai dengan kondisi masyarakat pada saat ini. Pengertian tentang Negara telah banyak di definisikan oleh para ahli filsuf Yunani Kuno, para ahli abad pertengahan, sampai abad modern. Beberapa pendapat tersebut antara lain:

a. Pendapat Aristoteles (Schmandt, 2002), negara adalah komunitas keluarga dan kumpulan keluarga yang sejahtera demi kehidupan yang sempurna dan berkecukupan.

b. Jean Bodin (Schmandt, 2002), negara sebagai pemerintahan yang tertata dengan baik dari beberapa keluarga serta kepentingan bersama mereka oleh kekuasaan berdaulat.

c. Riger Soltau, (Budiardjo, 2007; Agustino, 2007; Kaelan dan Achmad Zubaidi, 2007), negara adalah alat atau wewenang yang mengatur atau mengendalikan persoalan bersama atas nama masyarakat.

d. Robert M. Mac Iver (Soehino,1998;Agustino,2007), negara adalah asosiasa yang menyelenggarakan penertiban dalam suatu wilayah berdasarkan sistem hukum diselenggarakan oleh pemerintah diberi kekuasaan memeksa.

e. Miriam Budiardjo (2007), negara adalah suatu daerah teritorial yang rakyatnya diperintah oleh sejumlah pejabat dan berhasil menuntut 
dari warganya untuk ketaatan melalui kekuasaan yang sah.

\section{Teori Terjadinya Negara}

\section{a. Teori Teokrasi}

Menurut teori ini, negara berdasarkan kehendak Tuhan. Paham ini muncul bahwa keyakinan keagamaan bahwa Tuanlah maha pencipta di langit dan bumi, pemegang kekuasaan tertinggi, tiada kekuasaan di dunia ini yang tidak berasal dari tuhan, termasuk negara. Penganut teori ini Thomas Aquinas, Agustinus, FJ. Sthal, maupun Hegel.

\section{b. Teori Organik}

Teori ini pertama kali diperkenalakan oleh tinggal di wilayah geografis saja, tapi negara harus ada ikatan yang muncul yaitu keadilan. Negara muncul karena ada kebutuhan yang sangat banyak dan beragam.

1. Teori Perjanjian

Teori perjanjian masyarakat memandang terjadinya suatu Negara karena adanya perjanjian masyarakt.

2. Teori Kekuasaan

Menurut teori kekuasan, siapa yang berkemampuan untuk memiliki kekuasaan atau berhasil mencapai kekuasaan, selayaknya memegangg pucuk pemerintahan.

3. Teori Kedaulatan

Teori kedaulatan rakyat memandang keberadaan Negara karena adanya kekuasaan tertinggi yang mampu mengatur kehidupan bersama masyarakat (negara). 


\section{Bentuk Negara}

1. Negara Kesatuan (unitaris)

Negara kesatuan adalah Negara yang tersusun tunggal, Negara yang hanya berdiri satu Negara saja, tidak terdapat Negara dalam suatu Negara.Dalam pelaksanaan pemerintah derah di nrgara kesatuan dapat di laksanakan dengan dua alternative system, yaitu:Sistem desantralisasi, dimana daerah-daerah diberikan keleluasaan dan kekuasaan untuk mengurus rumah tangganya sendiri (otonomi) Sistem sentralisasi: dimana segala sesuatu urusan dalam Negara tersebut langsung diatur an di urus oleh pemerintah pusat, termasuk segala hal yang menyangkut pemerintahan dan kekuasaan di daerah.

2. Negara Serikat (federasi)

Negara serikat adalah Negara yang merupakan gabungan dari beberapa, kemudian menjadi negara-negara bagian dari pada suatu Negara serkat.

\section{Negara Indonesia}

Berdasarkan berbagai teori terjadinya negara, kedaulatan Negara, serta bentuk dan tujuan Negara, maka Negara Indoneia yang di proklamasikan tanggal 17 Agustus 1945, dapat dijelaskan secara teoristis sebagai berikut:

\section{Lahirnya Negara Indonesia}

Indonesia merdeka tanggal 17 Agustus 1945 dalam Proklamasi Kemerdekaan Indonesia yang melahirkan Negara Kesatuan Republik Indonesia. Negara Kesatuan RI bukanlah merupakan tujuan terakhir perjuangan bangsa Indonesia, melainkan merupakan alat untuk melanjutkan perjuangan bangsa Indonesia mencapai cita-cita, membentuk masyarakat adil 
makmur, aman sentosa berlandaskan pancasila. Meskipun ditinjau berdasarkan unsur-unsur yang membentuk negara, hampir semua negara memiliki kesamaan, namun ditinjau dari segi tumbuh dan terbentunya negara serta susunan negara, setiap negara di dunia ini memiliki spesifikasi serta ciri khas masing-masing. Demikian pula negara-negara lain di dunia tumbuh dan berkembang dengan ciri khas dan sejarahnya masing-masing.

Demikian pula bangsa dan Negara Indonesia tumbuh dan berkembang dengan dilatar belakangi oleh kekuasaan dan penindasan bangsa asing seperti penjajahan Belanda serta Jepang. Oleh karena itu bangsa Indonesia tumbuh dan berkembang dilatar belakangi oleh adanya kesatuan nasib, yaitu bersama-sama dalam penderitaan di bawah penjajahan bangsa asing serta berjuang merebut kemerdekaan. Selain itu yang sangat khas bagi bangsa Indonesia adalah unsur- unsur etnis yang membentuk bangsa itu sangat beraneka ragam, baik latar belakang budaya seperti bahasa, adat kebiasaan serta nilai-nilai yang dimilikinya. Oleh karena itu terbentuknya bangsa dan negara Indonesia melalui suatu proses yang cukup panjang. Sejak masa sebelum bangsa asing menjajah Indonesia, seperti masa kejayaan kerajaan Kutai, Sriwijaya, Majapahit dan kerajaan-kerajaan lainnya. Kemudian datanglah bangsa asing ke Indonesia maka bangsa Indonesia saat itu bertekad untuk membentuk suatu persekutuan hidup yang disebut bangsa, sebagai unsur pokok negara melalui Sumpah Pemuda 28 Oktober 1928. Isi sumpah itu merupakan suatu tekad untuk mewujudkan unsur-unsur negara yaitu satu nusa (wilayah) negara, satu bangsa (rakyat), dan satu bahasa, sebagai bahasa pengikat.

\section{Unsur-unsur Negara}

Menurut Oppenheim-Lauterpacht, unsur-unsur negara adalah:

1. Unsur pembentuk negara (konstitutif): wilayah/daerah, rakyat, pemerintah yang berdaulat

2. Unsur deklaratif: pengakuan oleh negara lain 


\section{Wilayah/Daerah}

1) Daratan

Wilayah daratan ada di permukaan bumi dalam batas-batas tertentu dan di dalam tanah di bawah permukaan bumi. Artinya, semua kekayaan alam yang terkandung di dalam bumi dalam batas-batas negara adalah hak sepenuhnya negara pemilik wilayah.

Batas-batas wilayah daratan suatu negara dapat berupa:

- Batas alam, misalnya: sungai, danau, pegunungan, lembah

- Batas buatan, misalnya: pagar tembok, pagar kawat berduri, parit

- Batas menurut ilmu alam: berupa garis lintang dan garis bujur peta bumi

2) Lautan

Lautan yang merupakan wilayah suatu negara disebut laut teritorial negara itu, sedangkan laut di luarnya disebut laut terbuka (laut bebas, mare liberum).

Ada dua konsepsi pokok tentang laut, yaitu:

1) Res Nullius, yang menyatakan bahwa laut tidak ada pemiliknya, sehingga dapat diambil/dimiliki oleh setiap negara;

2) Res Communis, yang menyatakan bahwa laut adalah milik bersama masyarakat dunia dan karenanya tidak dapat diambil/dimiliki oleh setiap negara. Tidak ada ketentuan dalam hukum internasional yang menyeragamkan lebar laut teritorial setiap negara. Kebanyakan negara secara sepihak menentukan sendiri wilayah lautnya. Pada umumnya dianut tiga (3) mil laut $( \pm 5,5 \mathrm{~km})$ seperti Kanada dan Australia. Tetapi ada pula yang menentukan batas 12 mil laut (Chili dan Indonesia), bahkan 200 mil laut (El Salvador). Batas laut Indonesia sejauh 12 mil laut diumumkan kepada masyarakat internasional melalui Deklarasi Juanda 
pada tanggal 13 Desember 1957.

3) Pada tanggal 10 Desember 1982 di Montego Bay (Jamaica), ditandatangani traktat multilateral yang mengatur segala sesuatu yang berhubungan dengan lautan, misalnya: permukaan dan dasar laut, aspek ekonomi, perdagangan, hukum, militer dan lingkungan hidup. Traktat tersebut ditandatangani 119 delegasi peserta yang terdiri dari 117 negara dan dua organisasi kebangsaan.

4) Udara

Wilayah udara suatu negara ada di atas wilayah daratan dan lautan negara itu.

Kekuasaan atas wilayah udara suatu negara itu pertama kali diatur dalam Perjanjian Paris pada tahun 1919 (dimuat dalam Lembaran Negara Hindia Belanda No.536/1928 dan No.339/1933). Perjanjian Havana pada tahun 1928 yang dihadiri 27 negara menegaskan bahwa setiap negara berkuasa penuh atas udara di wilayahnya. Hanya seizin dan atau menurut perjanjian tertentu, pesawat terbang suatu negara boleh melakukan penerbangan di atas negara lain. Demikian pula Persetujuan Chicago 1944 menentukan bahwa penerbangan internasional melintasi negara tanpa mendarat atau mendarat untuk tujuan transit dapat dilakukan hanya seizin negara yang bersangkutan. Sedangkan Persetujuan Internasional 1967 mengatur tentang angkasa yang tidak bisa dimiliki oleh negara di bawahnya dengan alasan segi kemanfaatan untuk semua negara dan tujuan perdamaian. 


\section{.Pandangan para ahli mengenai pengertia Bangsa:}

- Otto Bauer berpendapat bahwa bangsa adalah suatu kesatuan yagn terjadi karena persatuan yang telah dijalani rakyat.

- Kranenburg dalam bukunya “Allgemeine Staatslehre” mengaitkan konsepsi bangsa dengan budi pekerti rakyat.

- Jacobsen dan Lipman dalam buku "Political Science" menyatakan bahwa bangsa adalah suatu kesatuan budaya (cultural unity).

- Ernest Renan dalam pidatonya di Universitas Sorbone (Paris) pada tanggal 11 Maret 1882 menyatakan bahwa bangsa adalah satu jiwa atau satu azas kerohanian yang ditimbulkan oleh adanya kemuliaan bersama di masa lampau. Bangsa tumbuh karena adanya solidaritas kesatuan.

- G.S. Dipondo mengatakan bahwa rakyat hanyalah sebagian kecil dari bangsa, yaitu mereka yang tidak duduk dalam pucuk pimpinan. Sedangkan pengertian bangsa mencakup baik pimpinan maupun rakyat itu sendiri.

- Padmo Wahyono menggunakan istilah bangsa sebagai unsur negara: bangsa dari suatu negara jika dilihat secara perorangan berarti warga negara.

\section{PENUTUP}

- Negara merupakan suatu organisasi di antara sekelompok atau beberapa kelompok manusia yang secara bersama-sama mendiami suatu wilayah (territorial) tertentu dengan mengakui adanaya suatu pemerintahan yang mengurus tata tertib dan keselamatan. Demikianlah Makalah tentang Pengertian Negara yang saya buat, mohon maaf apabila ada kesalahan penulisan dan lainnya, semoga bermanfaat. 


\section{DAFTAR PUSTAKA}

Darmini Roza dan Laurensius Arliman S Peran Pemerintah Daerah Di Dalam Melindungi Hak Anak Di Indonesia, Masalah-Masalah Hukum, Volume 47, Nomor 1, 2018.

Laurensius Arliman S, Komnas HAM dan Perlindungan Anak Pelaku Tindak Pidana, Deepublish, Yogyakarta, 2015.

Laurensius Arliman S, Penguatan Perlindungan Anak Dari Tindakan Human Trafficking Di Daerah Perbatasan Indonesia, Jurnal Selat, Volume 4, Nomor 1, 2016.

Laurensius Arliman S, Problematika Dan Solusi Pemenuhan Perlindungan Hak Anak Sebagai Tersangka Tindak Pidana Di Satlantas Polresta Pariaman, Justicia Islamica, Volume 13, Nomor 2, 2016.

Laurensius Arliman S, Pelaksanaan Perlindungan Anak Yang Tereksploitasi Secara Ekonomi Oleh Pemerintah Kota Padang, Veritas et Justitia, Volume 2, Nomor 1, 2016.

Laurensius Arliman S, Kedudukan Ketetapan MPR Dalam Hierarki Peraturan PerundangUndangan Di Indonesia, Lex Jurnalica, Volume 13, Nomor 3, 2016.

Laurensius Arliman S, Komnas Perempuan Sebagai State Auxialiary Bodies Dalam Penegakan Ham Perempuan Indonesia, Justicia Islamica, Volume 14, Nomor 2, 2017.

Laurensius Arliman S, Peranan Pers Untuk Mewujudkan Perlindungan Anak Berkelanjutan Di Indonesia, Jurnal Ilmu Hukum Tambun Bungai, Volume 2, Nomor 2, 2017.

Laurensius Arliman S, Mewujudkan Penegakan Hukum Yang Baik Untuk Mewujudkan Indonesia Sebagai Negara Hukum, Jurnal Hukum Doctrinal, Volume 2, Nomor 2, 2017.

Laurensius Arliman S, Participation Non-Governmental Organization In Protecting Child Rights In The Area Of Social Conflict, The 1st Ushuluddin and Islamic Thought International Conference (Usicon), Volume 1, 2017.

Laurensius Arliman S, Partisipasi Masyarakat Dalam Pembentukan Perundang-Undangan Untuk Mewujudkan Negara Kesejahteraan Indonesia, Jurnal Politik Pemerintahan Dharma Praja, Volume 10, Nomor 1, 2017, https://doi.org/10.33701/jppdp.v10i1.379.

Laurensius Arliman S, Peran Komisi Perlindungan Anak Indonesia Untuk Mewujudkan Perlindungan Anak, Jurnal Respublica Volume 17, Nomor 2, 2018.

Laurensius Arliman S, Menjerat Pelaku Penyuruh Pengrusakan Barang Milik Orang Lain Dengan Mempertimbangkan Asas Fungsi Sosial, Jurnal Gagasan Hukum, Volume 1, Nomor 1, 2019. 
Laurensius Arliman S, Ilmu Perundang-Undangan Yang Baik Untuk Negara Indonesia, Deepublish, Yogyakarta, 2019.

Laurensius Arliman S, Isdal Veri, Gustiwarni, Elfitrayenti, Ade Sakurawati, Yasri, Pengaruh Karakteristik Individu, Perlindungan Hak Perempuan Terhadap Kualitas Pelayanan Komnas Perempuan Dengan Kompetensi Sumber Daya Manusia Sebagai Variabel Mediasi, Jurnal Menara Ekonomi: Penelitian dan Kajian Ilmiah Bidang Ekonomi, Volume 6, Nomor 2, 2020.

Laurensius Arliman S, Pendidikan Kewarganegaraan, Deepublish, Yogyakarta, 2020.

Laurensius Arliman S, Makna Keuangan Negara Dalam Pasal Pasal 23 E Undang-Undang Dasar 1945, Jurnal Lex Librum, Volume 6, Nomor 2 Juni 2020, http://dx.doi.org/10.46839/1ljih.v6i2.151.

Laurensius Arliman S, Kedudukan Lembaga Negara Independen Di Indonesia Untuk Mencapai Tujuan Negara Hukum, Kertha Semaya Journal Ilmu Hukum, Volume 8, Nomor 7, 2020.

Laurensius Arliman S, Pelaksanaan Assesment Oleh Polres Kepulauan Mentawai Sebagai Bentuk Pelaksanaan Rehabilitasi Bagi Pecandu Dan Korban Penyalahgunaan Narkotika, Jurnal Muhakkamah, Volume 5, Nomor 1, 2020.

Laurensius Arliman S, Aswandi Aswandi, Firgi Nurdiansyah, Laxmy Defilah, Nova Sari Yudistia, Ni Putu Eka, Viona Putri, Zakia Zakia, Ernita Arief, Prinsip, Mekanisme Dan Bentuk Pelayanan Informasi Kepada Publik Oleh Direktorat Jenderal Pajak, Volume 17, No Nomor, 2020.

Larensius Arliman S, Koordinasi PT. Pegadaian (Persero) Dengan Direktorat Reserse Narkoba Polda Sumbar Dalam Penimbangan Barang Bukti Penyalahgunaan Narkotika, UIR Law Review, Volume 4, Nomor 2, 2020, https://doi.org/10.25299/uirlrev.2020.vol4(1).3779.

Laurensius Arliman S, Tantangan Pendidikan Kewarganegaraan Pada Revolusi 4.0, Ensiklopedia Sosial Review, Volume 2, Nomor 3, 2020.

Muhammad Afif dan Laurensius Arliman S, Protection Of Children's Rights Of The Islamic And Constitutional Law Perspective Of The Republic Of Indonesia, Proceeding: Internasional Conference On Humanity, Law And Sharia (Ichlash), Volume 1, Nomor 2, 2020.

Otong Rosadi danLaurensius Arliman S, Urgensi Pengaturan Badan Pembinaan Idelogi Pancasila Berdasarkan Undang-Undang Sebagai State Auxiliary Bodies yang Merawat Pancasila dalam Perspektif Hak Asasi Manusia, Prosiding Konferensi Nasional Hak Asasi Manusia, Kebudayaan dan Tujuan Pembangunan Berkelanjutan Indonesia pada Masa Pandemi Covid-19: Tantangan untuk Keilmuan Hukum dan Sosial Volume 1, Universitas Pancasila, Jakarta, 2020. 
